\title{
Tribal Priorities
}

\author{
Andrew Shryock* \\ Department of Anthropology, University of Michigan, Ann Arbor, MI, USA \\ ${ }^{\star}$ Corresponding author. Email: ashryock@umich.edu
}

In the oral traditions of Jordan's Balga tribes, one event occurs many times: local shaykhs are invited to a feast by the Turks, and at this feast the shaykhs are attacked, arrested, or killed. Sometimes it is the Ottomans who are betrayed by their bedouin hosts. Either way, they should have seen it coming-that is usually the narrator's conclusion-but the lure of hospitality was strong. Something about these encounters was worth the risk of ending up in manacles, or dead.

The stakes for participating in this roundtable are lower, but something tells me to be wary when scholars who study tribes and tribalism are invited to a feast that, to put it bluntly, is designed to consider why and how tribes are still with us. Why, after all this time? How, despite all their departures from the political expectations of that hypothetical beast, "modernity"? Do I hear manacles clanking in the background? If so, why am I eager to attend this feast? And why do I identify with the tribal shaykhs, who seldom trusted state officials, but relied on them for coin, weapons, titles, and recognition? Clearly, things can be said in the idiom of hospitality that are hard to express in any other way.

I have spent much of my anthropological career studying tribes, as a guest, protected person, and ethnographer. The people I've worked with in Jordan and Yemen are quite proud of their membership in the entities we call, in English, "tribes." When speaking English, they also use this term, along with related ones, like "family" and "clan." In Jordan, the groups in question are called 'asha'ir (sing. 'ashìra); in Yemen, the preferred term is qabila (pl. qabä'il). An 'ashìra, in Jordan, is an odd mix of qualities and claims. It always has a name; it asserts a special relationship to physical space, or territory, or patterned movements through both; it has a known history, which its members tell in relation to, and in opposition to, other 'asha'ir; its structure is segmental, or nested, with named groups embedded in named groups, sometimes using a genealogical idiom, sometimes an idiom of alliance; and it has legal traditions, often distinct from Islamic or state law, that include judgment, fines, oaths, settlements, and elaborate procedures for limiting the interactions of disputing parties. In Jordan, the members of 'asha'ir place great value on their collective reputation, good origins, generosity, and the ability to protect themselves and others. These things influence present-day interactions among 'ash'a'ir; they also pervade the language of tribal historical claims and determine who has the authority to make them. ${ }^{1}$

All of this is vital not only to tribespeople, but to the Hashemite state, which has catered to, suppressed, and attempted to co-opt and reconfigure 'asha'ir since the 1920s, when Abdullah I and his British patrons started the small (political) business that would grow into the Hashemite Kingdom of Jordan. It is cliché to say that the tribes are the backbone of the Hashemite regime. It is better to say 'ash'ir $i r$ are entangled in multiple state institutions, variously supporting and resisting them. The tribes are not a guaranteed bloc of pro-state tendencies, trading loyalty to the Hashemites in exchange for public sector jobs and benefits deriving from military service. During fieldwork in Jordan in the late 1980s, I discovered how critical of the state, and how distrustful of government, tribal leaders and followers could be. A leitmotif of political discourse among the Balga tribes was King Hussein's supposed favoritism toward Palestinians (as well as Circassians, Chechens, Christians, and even the Muslim Brotherhood). The benefits tribespeople received from the state were interpreted as signs of respect. When non-tribal critics described them as payoffs or entitlements, my tribal interlocutors suggested

\footnotetext{
${ }^{1}$ A thorough, distinctively Jordanian account of this terrain is provided by anthropologist and tribesman Dr. Ahmad 'Uwaydi al- 'Abbadi, in Muqaddima li-Dirasat al-'Asha'ir al-Urduniyya (Amman: al-Dar al-'Arabiyya, 1985).

( $\odot$ The Author(s), 2021. Published by Cambridge University Press. This is an Open Access article, distributed under the terms of the Creative Commons Attribution licence (http://creativecommons.org/licenses/by/4.0/), which permits unrestricted re-use, distribution, and reproduction in any medium, provided the original work is properly cited.
} 
that bribery would not work on them, and even if it could their support would certainly warrant a much higher price! The anti-corruption sentiment now roiling in Jordan, and linked in popular media to the Arab Spring, has been present for decades. So has the tendency to speak of the Hashemites as a small family dependent on the good graces of a local population who received them in 1920 as guests, who questioned or challenged their right to rule (in several armed uprisings that are still spoken of openly and with pride), and who eventually worked out terms of political support that acknowledged the authority, and the British military backing, of the Hashemites in return for inclusion in governance and respect for the shaykhs of influential tribes. This is not textbook history, and it is seldom nuanced, but it does sum up nicely the origins of a regime actively engaged in the affairs of named tribes and their leaders. ${ }^{2}$ It also highlights the general patterns of malfunction the system guarantees. For every tribal group on the good side of the king, there is another (often a faction within the same tribe) that is boxed out. For every shaykh the state favors, several others will denounce him as corrupt. This sensitivity to recognition and exclusion is not simply a result of tribal divisiveness, or the "divide and rule" policies of the state. Instead, it is rooted in an ethos that insists on attention, sharing, mediated access to privilege, and mutual respect. The emergence of alternative constituencies (Palestinians, Iraqis, Syrians) and the agendas of powerful external actors (the US, the World Bank, the Gulf states, Israel) threaten to sideline the East Bank 'asha'ir, who are a demographic minority in Jordan. "Do not forget us" is their common advice to government officials and tribal leaders. Fear of being forgotten, of not being invited to the feast, drives tribal political activism. Being told that tribes are a thing of the past, or a creation of the colonial or postcolonial state, or morally and politically retrograde, or a false rendering of class formations, or an Orientalist fixation: none of this messaging is reassuring to the millions of Jordanians for whom tribal identities are important.

Yet implications of backwardness are pervasive. The English words "tribe," "tribal," and "tribalism" are strongly associated with primitivism and Victorian social evolutionism, and there is great reluctance among scholars to use them as analytical terms. Anthropologists at work in other world regions, notably Africa, have opted for newer terms: "ethnic group," "Indigenous people," "language communities." This corrective maneuver has been useful in countries where the sociopolitical configurations labeled tribes clearly did not preexist colonial vocabularies and logics of rule. Abandoning these English words has enabled anthropologists and historians to analyze identity formations, ranging from the genealogical to the nationalist, in more rigorous ways. It also has brought scholars into alignment with postcolonial regimes eager to promote national unity or, just as often, to favor certain ethnic groups in practice without being accused of tribalism as policy. ${ }^{3}$

Despite all this, the English term "tribe" still circulates widely in Arab-majority states. This is so because its Arabic equivalents, 'ashìra and qabila, have deep roots. State formations across the Middle East and North Africa have included tribally organized populations for millennia. ${ }^{4}$ Ibn Khaldun, writing in the 14th century CE, made tribe-state relations central to his model of human history. ${ }^{5}$ If he needed more than intellectual justification for doing so, he could reference the Qur'an, in which God tells us that he created humans as "peoples and tribes" (shu'ub wa qaba’’il), to help us know one another (49:13). Associating contemporary Arab tribes with the ideas of primitivism entertained by European travel writers and British colonial officers is not invariably a mistake-Orientalism and empire can turn almost any local identity into evidence of backwardness-but stopping there is a recipe for skewed political analysis and bad history writing. Often, tribal groups have been central to anti-colonial, anti-imperial resistance movements. ${ }^{6}$ Hence, the pervasive interest in co-opting or crushing them, a strategy that appeals to local authorities as much as it does to the US military and its allies in Iraq, Afghanistan, Libya, Somalia, and

\footnotetext{
${ }^{2}$ For the nuanced version, see Yoav Alon's The Making of Jordan: Tribes, Colonialism and the Modern State (London: I. B. Tauris, 2007).

${ }^{3}$ This terrain is explored by Adam Kuper in The Reinvention of Primitive Society: Transformations of a Myth (London: Routledge, 2005).

${ }^{4}$ An overview is available in Tribes and State Formation in the Middle East, ed. Philip Khoury and Joseph Kostiner (Berkeley, CA: University of California Press, 1990).

${ }^{5}$ The Muqaddimah, trans. Franz Rosenthal, ed. N. J. Dawood (Princeton, NJ: Princeton University Press, 1967).

${ }^{6}$ For an example drawn from Italian colonials wars, see E. E. Evans-Pritchard, The Sanusi of Cyrenaica (Oxford, UK: Clarendon Press, 1949).
} 
other sites in the global war on terror. ${ }^{7}$ Middle Eastern nation-states have found aspects of tribal heritage useful in building public cultures, even if that heritage de-emphasizes named tribal groups and opts for kitschy displays of coffee pots, old swords and daggers, and idealized elements of costume and cuisine. ${ }^{8}$ State manipulation of tribal identities, along with the advent of mass literacy, has led frequently to an efflorescence of genealogical research and the gathering and publication of oral traditions. ${ }^{9}$

When regimes falter, tribes can morph from nostalgia platforms into armed militias, lending intelligence and firepower to movements that, in international media, are more easily described using a vocabulary of political parties, insurgencies, terrorist organizations, state actors, and US or Russian geopolitical interests. Other contributors to this forum show how hard it can be to track and interpret tribal participation in the wars in Yemen and Syria, yet how essential this participation is to outcomes on the ground. ${ }^{10}$ Even in Jordan, a country whose brand is stability, any hint of unrest comes with insinuations, or reliable evidence, of tribal involvement. The recent bad blood between King Abdullah II and his brother, Prince Hamza, was true to form: behind the critical Prince were several critical tribesmen (members of the Majali, a politically prominent family from Karak, among others). If, as many observers claimed, rumors of an incipient coup were exaggerated by Abdullah's supporters, then adding tribes to the mix made for a better story, one more urgent and believable. Every sizable 'ashira in Jordan has a long history of contest and collusion with the Hashemites. ${ }^{11}$ And Jordan's prisons have, since the Arab Spring, been home to hundreds of political detainees whose causes, whether nationalist, reformist, or oriented toward human rights, involve the mobilization of conspicuously tribal constituencies. ${ }^{12}$

If relatively few scholars today study tribes and tribalism in the Arab countries, or in the Middle East more generally, it is not because the topic is unimportant. Rather, it is because the topic is of obvious significance (why else would journalists constantly trip over it?) but is difficult to analyze in terms preferred by mainline academics, progressive political movements, and Arab intellectuals (diasporic and in-region), who tend to dismiss attention to tribes in much the way anti-imperial and postcolonial thinkers in other world regions have done. Deeb and Winegar, describing contemporary anthropology in Arab-majority societies, go straight to the point: "Tribal social organization has practically vanished as a topic of concern for scholars, though not for policy makers, right-wing analysts, and anthropologists embedded with the U.S. military, many of whom persist in using stereotyped notions of tribal structures to explain political violence."13 Of course, the trending topics (gender, Islam, politics and popular culture, reform-oriented social movements) also are of interest to policy makers, right-wing analysts, and military types. The generational shift toward research in cities cannot quite account for lack of interest in tribes, since tribal populations are moving into cities as well, and cities are encroaching on tribal areas. Despite these transitions, many scholars insist that attention to tribes is exoticizing or, in more knee-jerk fashion, they simply do not like people who identify as tribal, seeing them as more enemy than friend, as more representational liability than asset. ${ }^{14}$

\footnotetext{
${ }^{7}$ For a recent survey, see Tribes and Global Jihadism, ed. Virginie Collombier and Olivier Roy (London: Oxford University Press, 2017).

${ }^{8}$ For analysis of material and public cultures, see Linda Layne, Home and Homeland: The Dialogics and Tribal and National Identities in Jordan (Princeton, NJ: Princeton University Press, 1994); and Miriam Cooke, Tribal Modern: Branding New Nations in the Arab Gulf (Berkeley, CA: University of California Press, 2014).

${ }^{9}$ For related studies, see Andrew Shryock, Nationalism and the Genealogical Imagination: Oral History and Textual Authority in Tribal Jordan (Berkeley, CA: University of California Press, 1997); and Nadav Samin, Of Sand or Soil: Genealogy and Tribal Belonging in Saudi Arabia (Princeton, NJ: Princeton University Press, 2015).

${ }^{10}$ Marieke Brandt, Tribes and Politics in Yemen: A History of the Houthi Conflict (Oxford, UK: Oxford University Press, 2017); Haian Dukhan, State and Tribes in Syria: Informal Alliances and Conflict Patterns (London: Routledge, 2018).

${ }^{11}$ For the Bani Sakhr case, see Yoav Alon, The Shaykh of Shaykhs: Mithqal al-Fayiz and Tribal Leadership in Modern Jordan (Stanford, CA: Stanford University Press, 2016).

${ }^{12}$ An excellent account of this activism is provided by Sean L. Yom in "Tribal Politics in Contemporary Jordan: The Case of the Hirak Movement," Middle East Journal 68, no. 2 (2014): 229-47. For the effects of social media on tribal politics and practices of dispute, see Geoffrey Hughes "Cutting the Face: Kinship, State, and Social Media Conflict in Networked Jordan," Journal of Legal Anthropology 2, no. 1 (2018): 49-71.

${ }^{13}$ Lara Deeb and Jessica Winegar, “Anthropologies of Arab Majority Societies," Annual Review of Anthropology 41 (2012): 540.

${ }^{14} \mathrm{I}$ base this claim on informal conversations with academic colleagues, who can be disturbingly frank about their distaste for so-called tribes. In Jordan, it is not unusual for sophisticated people to call 'ashayir "Red Indians" (al-hunud al-humr), an obvious appropriation of older British attitudes.
} 
In Jordan, I have done ethnography among the 'Abbad and 'Adwan tribes. They are citizens of a modern state, and most of them live in towns that have become commuter suburbs of Amman and Salt. I have recorded oral histories from illiterate men who grew up in tents, whose children and grandchildren are college-educated, multilingual urbanites. Hashemite Jordan is a society that valorizes, alongside socioeconomic development, things commonly held to be traditional, if not ancient: monarchy, the authority of Prophetic revelation and descent, ancestral Arabness, and a wealth of institutions and lifeways associated with 'asha' 'ir. To see any of this as primitive is an investment, a choice; to see all of it as socially constructed is merely to admit that it is part of everyday life. What is more vital, and problematic, is the extent to which tribal belonging, and Jordanian-ness of a certain kind, is framed as prior to the state, to its laws and leaders, and to the forms of political community it authorizes. This is partly a claim to historical firstness, and as such it is often demonstrably true. 'Abbadis and 'Adwanis lived in the Balga long before Hashemite Jordan was established. But priority also is a claim to moral precedence, to greater importance and consideration based on descent, historical dominance, and the ability to protect and represent weaker parties, who should not pretend to be the patrons or equals of 'ashä'ir. It is this sense of priority that animates the old Balgawi stories of disastrous feasts. The roles of host and guest are not open to everyone. The feast is a truce, and a bond. At stake, for the shaykhs and the Ottomans, was a model of sovereignty that legitimized them both: because I am your host now, you can be my host later; we owe each other favors and respect; our relationship is prior to others; it is our privilege; we are beholden to each other. This sensibility brought tribal and state authorities to the feast, and it made treachery there impossible to forget. ${ }^{15}$

Anyone who listens to the rhetoric of reform spoken by tribal activists in Jordan today will note how prominent themes of hospitality are to it. As Abdullah II asserts his mastery over one house, one tribe, and one big, Jordanian family, a vocal subset of tribal reformists depict the Hashemites as bad guests-or occupiers-and themselves, the tribes, as long-suffering hosts. Why, they ask, has the guest come to inhabit so much of the house? Hashemite largess is portrayed as disenfranchisement. According to a communique issued by Jordanian military retirees in 2007, the "Jordanian citizen does not presently have any right to anything; medical treatment is an act of benevolence, food is an assistance, high cost education is a favor, housing is a gift, and clothing is a charitable act. It is as though the citizen lives as a slave in a fiefdom."16

Since 2011, some tribal protestors have been calling for a constitutional monarchy, others for a republic. ${ }^{17}$ Most insist only on "reform," lest they trigger a system collapse that ends, as almost everyone believes it would, in a bloody civil war. A tactical distance between tribal and non-tribal activists has persisted throughout because priority is often the underlying issue, not citizenship plain and simple. This is why Prince Hamza's frequent visits to tribal diwān s are treated as both a virtue and a threat to his brother's authority; whatever motivates the visits, they are a form of attention that solidifies and prioritizes tribal critique. To understand why this is important, one must take seriously the moral assumptions built into local notions of house, host, and guest. ${ }^{18}$ Yet refusal to do so has been a common choice of Western scholars in the Balga since their arrival in the 19th century. The feast, as a display of graces, and the house, as a site of mutual protection and respect, are often seen as spaces the diligent scholar must work around in pursuit of knowledge.

A telling example is Captain Charles Warren, who mapped antiquarian sites in the Balga in 1867, just days before the Ottomans invaded the region and brought it under state control. His account of the hospitality he received from his 'Adwani protectors, Shaykh Dhiyab Hamud and Shaykh Goblan al-Nimr, is

\footnotetext{
${ }^{15}$ I examine these ideas in "Breaking Hospitality Apart: Bad Hosts, Bad Guests, and the Problem of Sovereignty," Journal of the Royal Anthropological Institute 18, no. S1 (2012): S20-33.

${ }^{16}$ Quoted in Jamal al-Shalabi and Yahya Ali, "The Crisis of the Center with the Peripheries in Jordan: The Hour of Confrontation Has Struck." Confluences Méditerranée 85, no. 2 (2013): 75-86.

${ }^{17}$ Dr. Ahmad Oweidi al-Abbadi told me in 2011 that Jordan would be a republic within two years. He made the same prediction on YouTube in 2012 and then spent two months in prison (Jordan Days Web TV, 21 January 2012, https://www.youtube. com/watch?v=eBixstEx2UY).

${ }^{18}$ For an analysis that attempts this, see Andrew Shryock and Sally Howell, "Ever a Guest in Our House': The Amir Abdullah, Shaykh Majid al-'Adwan, and the Practice of Jordanian House Politics, as Remembered by Umm Sultan, the Widow of Majid," International Journal of Middle East Studies 33, no. 2 (2001): 247-69.
} 
grudging. Dhiyab expected Warren to sit with him for three hours while a feast of lamb and rice was being prepared, and Goblan pressed hard for Warren to give Dhiyab one of the captain's best pistols. It was all a great irritation to Warren, who saw such rituals as necessary impediments to his free movement through an unsafe, ungoverned region. "[I]n spite of the soothing effects of their hospitality, and dinner," he writes, "I was able to steel myself against what I considered an imposition, and told Diab I had brought nothing for him; but that if I saw anything in Jerusalem when I went back that I thought he would like, I would send it to him." 19 Warren says he later sent a "small present" to Diab. The lesson he draws for his readers, however, is an unwitting parable. It shows how handicapped Captain Warren was in his interactions with his 'Adwani colleagues.

\begin{abstract}
Although the Bedouins are bound to feed one gratis by their own laws, yet I always feel a certain amount of compunction in receiving anything without giving an equivalent, because of our civilised customs, which forbid one treating them in return as hospitably as they treat us: thus, when Goblan comes to see me, I can't ask him to dinner, or into the drawing room, but give over an outhouse to his use, and supply his bed with carpets from the floor; and even the carpets I begrudge, because they have to be hung up out of doors for several days after a visit for fear of vermin having been left on them. It was on that account that I did not wish to feed with Diab, for I knew that at the least it would cost three pounds sterling, and lose me half a day's work. ${ }^{20}$
\end{abstract}

To dismiss these observations as British imperial racism is too easy. Few of us will ever contend with heavily armed guests who infect our bedding with fleas and lice; and why assume that Goblan wanted to socialize in the awkward domestic spaces of his English protégés? If we are offended by Warren's passage, it is because neither he nor Goblan is alien to us. The hierarchy, lack of equivalent gestures, inability to offer respect, and the guilt civilized dispositions produce are familiar aspects of Orientalism. Their grip on scholarship and regional politics is many times more debilitating than anything a more direct engagement with tribalism might bring. The scandal for Warren, and for us, his self-conscious, judgmental doubles, is the insistent pull of Goblan, who is (still) there, offering us hospitality and protection, coming to see us, demanding time, gifts, and respect. He reminds Warren of all the Balgawi spaces in which he is welcome, but over which he is not sovereign. The priority of these spaces is what my 'Abbadi and 'Adwani hosts wanted me to experience when they invited me into their homes, and into their histories.

\footnotetext{
${ }^{19}$ Charles Warren, “Expedition to the East of Jordan, July and August, 1867," Palestine Exploration Fund Quarterly Statement 1 (1870): 298.

${ }^{20}$ Ibid.
}

Cite this article: Shryock A (2021). Tribal Priorities. International Journal of Middle East Studies 53, 512-516. https://oi.org/ $10.1017 /$ S0020743821000830 